\title{
Survey on Ethnobotanic Value of Banana (Musa spp; Musaceae) in Bali Province, Indonesia
}

\author{
Topik Hidayat ${ }^{1,4^{*}}$, Himalaya Wana Kelana ${ }^{1}$, Dhiyassalam Imam Anshori Ismanto ${ }^{1}$, Karlia Meitha ${ }^{2,3}$ \\ ${ }^{1}$ Department of Biology Education, Universitas Pendidikan Indonesia (UPI), Bandung, Indonesia \\ ${ }^{2}$ School of Life Science and Technology, Institut Teknologi Bandung (ITB), Bandung, Indonesia \\ ${ }^{3}$ Bali International Research Center for Banana, Udayana University (UNUD), Bali, INdonesia \\ ${ }^{4}$ ForMIND Institute, Bandung, Indonesia
}

ARTICLE INFO

Article history:

Received February 8, 2017

Received in revised form June 30, 2017

Accepted November 30, 2017

\section{KEYWORDS:}

Bali province,

Banana,

Ethnobotany,

Indigenous knowledge

\begin{abstract}
Bali, one of Indonesia island, is a region inhabited by a large number and varied banana (Musa spp; Musaceae). Many varieties of banana have been utilized by local peoples since long time ago as traditional medicine, edible material, used in traditional ceremony and others. However, information regarding the knowledge on ethnobotany of banana in Bali remains scattered and is not documented well. The purpose of this study was to evaluate and document the ethnobotanic values of bananas in Bali. Ethnobotanic data was collected through focus group discussion (FGD), surveys and interviews from 9 study sites (1 city and 8 regencies) with one or two villages represented each site. Ethnobotanical value of banana was determined by Local User's Value Index (LUVI) with Pebble Distribution Method (PDM). Subsequently, data obtained was analysed using simple statistic description. Results showed that as many as 44 varieties of banana in Bali were documented. Local peoples have been utilizing banana in their daily life for ritual as indicated by higher LUVI (0.4867), followed by food $(0.3)$, medicine $(0.1533)$, and other (0.06). On the basis of testimony of respondents, indigenous knowledge of peoples in Bali about banana is vertically transmitted from parents to their children $(\mathbf{9 8 \%})$. This study provided a valuable information of how the local peoples manage and conserve the banana and its nature.
\end{abstract}

\section{Introduction}

Bananas represent one of the mega-diversity components of Indonesia flora and fauna. Bananas are considered as popular tropical fruit commodity due to the high level of consumption worldwide, making them as fruits with bright prospect in the future (Jumari 2000; Daniells et al. 2001). This herb is one among few plants, which all parts of it is useful for supporting many needs of human (Espino et al. 1992). The most common use of bananas are for food (cooked or fresh), livestock feed, domestic material, shelter, ornament, medicine, as symbol in ceremonial and ritual events, and many other uses. For some indigenous communities, in the context of their local beliefs, bananas correspond to philosophical meaning about connecting to life processes, and providing lessons about ethics (De Beer et al. 2011; Henderson et al. 2012; Hapsari et al. 2017).

\footnotetext{
* Corresponding Author.

E-mail Address: topikhidayat@upi.edu
}

Several studies have been conducted to investigate the distribution and benefits of bananas for daily life in some local communities in Indonesia. For instance, Sasak community utilizes Punti Manila banana (Musa textilis) as woven weaving materials (pseudostem), natural dyes (leave), and food wrapping (fruit). Punan community in Malinau-East Kalimantan symbolizes two varieties of wild banana Musa borneensis Becc. var flavida and Musa acuminata colla var. microcarpa as 'land certificate' (Simmonds 1959). On top of that, Rai et al. (2016) suggested that all parts of the banana species are useful as a drug, such as flowers for bronchitis and sap for epilepsy.

This presented study is one of the efforts to evaluate and document the ethnobotanic values of bananas in Bali, including the inventory of local banana cultivars, local naming, their usefulness for the communities either for clothing, boards, medicine or ritual ceremonies related to local knowledge and how the knowledge is transmitted. This study is expected to contribute to the increasingly urgent pressures of globalization to preserve the biodiversity of banana and its local knowledge. 


\section{Materials and Methods}

\subsection{Study Sites}

Bali Province is geographically located at the coordinate point position of $08^{\circ} 03^{\prime} 40-08^{\circ} 50^{\prime} 48^{\prime \prime}$ SL and $114^{\circ} 25^{\prime} 53^{\prime \prime}-115^{\circ} 42^{\prime} 40^{\prime \prime}$ EL (Figure 1). Bali province consists of 1 city and 8 regencies covering Jembrana, Tabanan, Badung, Gianyar, Klungkung, Bangli, Buleleng, Karangasem, and Denpasar districts. Ethnobotany survey for Bali bananas was conducted in one to two villages in each city or regency. Selection was done purposively based on information obtained from the local agricultural service on the area that produces plentiful of bananas, as well as from fruit merchants and local residents. The details of survey schedule and route are presented in Table 1.

\subsection{Collection and Data Analysis}

Data collection was conducted by focus group discussion (FGD), surveys and interviews in all visited villages or banjar in Bali. Used instruments included

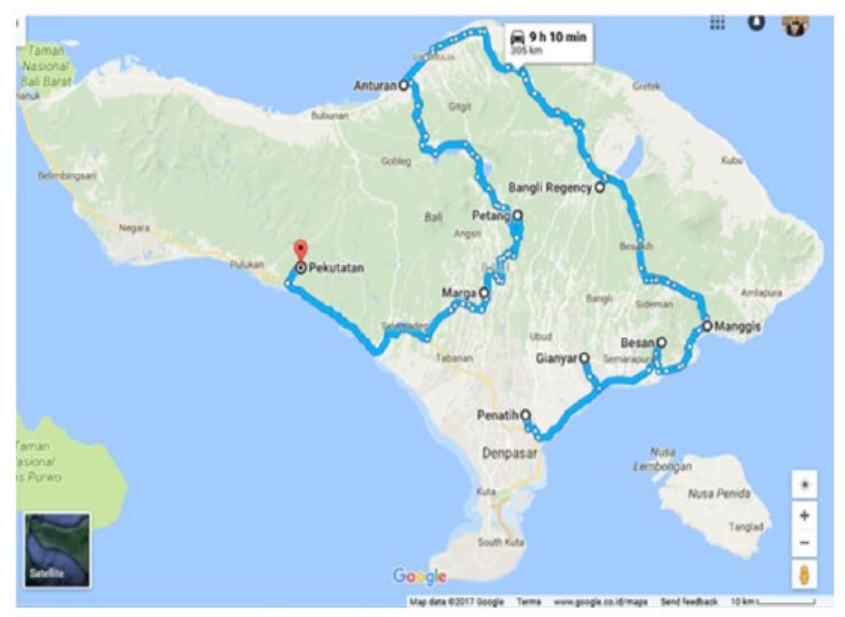

Figure 1. Map of survey sites field notes, observation and interview sheets. This study was conducted using a purposive sampling method (Tongco 2007) to obtain valuable information from respondents regarding their knowledge of local bananas. The snowball sampling technique was also used to contact and obtain key information from respected profiles such as chief of the village, religion leaders, and community elders (Bernard 2002). At least two respondents from each village were selected to conduct personal interviews, through open-ended and semi-structured questions (Oishi 2002; Martin 2004; Dickinson 2013).

The information obtained included the inventory of a local name of a banana cultivar, synonym and meaning if any, local knowledge and knowledge about bananas, the reasons for planting certain banana cultivars, and knowledge transmission patterns as an effort to conserve local banana germplasm. The uses of the body part of banana were categorized into root, tuber, midrib, leaf, heart and inflorescence, and fruit. Also, the uses of banana were grouped into four catagories: as food (consumed by the locals), ritual (ceremony and traditional needs), medicine (traditional medicines), and others (such as livestock feeds, food wrapping, ornamental, etc). The questions also included the philosophical values and usefulness of bananas in cultural and religious rituals, food, medicines and other uses in daily life. Ethnobotanical value of banana was determined by Local User's Value Index (LUVI) with Pebble Distribution Method (PDM) (Suryadarma 2008) (Figure 2).

\section{Results}

\subsection{Respondents Profile}

There were 160 respondents in his study and the majority (98\%) were Balinese ethnic with Hindu religion, while the other $2 \%$ were immigrants with Islam as religious affiliation. Respondents were chosen from various backgrounds, genders, and

Table 1. Study sites of bananas ethnobotanical study in Bali. The visited villages represent each of 1 city and 8 regencies in the province

\begin{tabular}{lll}
\hline City/Regency & Village/Banjar & Survey Schedule \\
\hline Denpasar & Penatih Village & Monday, 17 July 2017 \\
Gianyar & Kerta Village - Payangan & Tuesday, 28 July 2017 \\
Klungkung & Besan Village \& Dawan Village & Wendnesday, 19 July 2017 \\
Karangasem & Rendang Villlage & Thursday, 20 July 2017 \\
Bangli & Jehem Village \& Penglipuran Village & Friday, 21 July 2017 \\
Buleleng & Anturan Village & Sunday, 23 July 2017 \\
Badung & Abiansemal Village & Monday, 24 July 2017 \\
Tabanan & Petiga Village & Tuesday,25 July 2017 \\
Jembrana & Pengeragoan Village, Banjar Badingkayu & Wendnesday, 26 July 2018 \\
\hline
\end{tabular}


ages in order to obtain comprehensive data on the uses of bananas by the people of Bali. Some of the respondents were from indigenous stakeholders such as traditional leaders, community head (Kelian), and Pekaseh. Other respondents were government officials, village officials, private employees, banana traders, farmers, teachers and students. Ratio of respondents' ethnicities and occupations are depicted in Figure 3.

We had 97 male respondents (61\%) and 63 female (39\%). Based on age range, the respondents were clustered into four groups: respondents age < $15,15-34,35-54$, and $\geq 55$ years old (Figure 4 ). The results showed that the average respondents in each regency were in the age group of 15-34 years and 3554 years. According to Winarso (2014) and Hapsari
(2017), respondents from those age groups are in the productive stage for learning.

\subsection{Inventory of Bali Banana Diversity}

During the expedition in Bali, several banana (biu in local dialect) cultivars were discovered and identified by the biodiversity team.

\subsection{Ethnobotanic Value}

Bananas are very important for the people of Bali, especially for the needs of ritual (ceremonies and traditions) as indicated by higher LUVI (0.4867), followed by food (0.3), medicine (0.1533), and other (0.06) (Figure 5). Free listing of local banana diversity

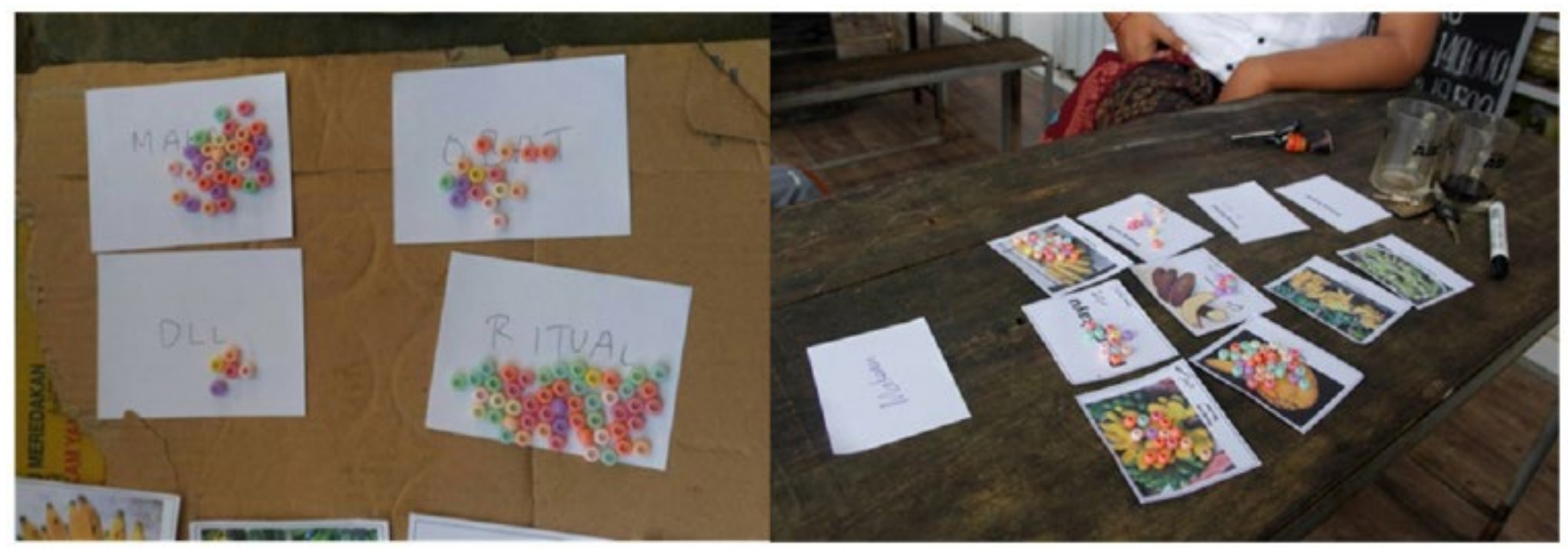

Figure 2. Pebble Distribution Method of ethnobotany data collection

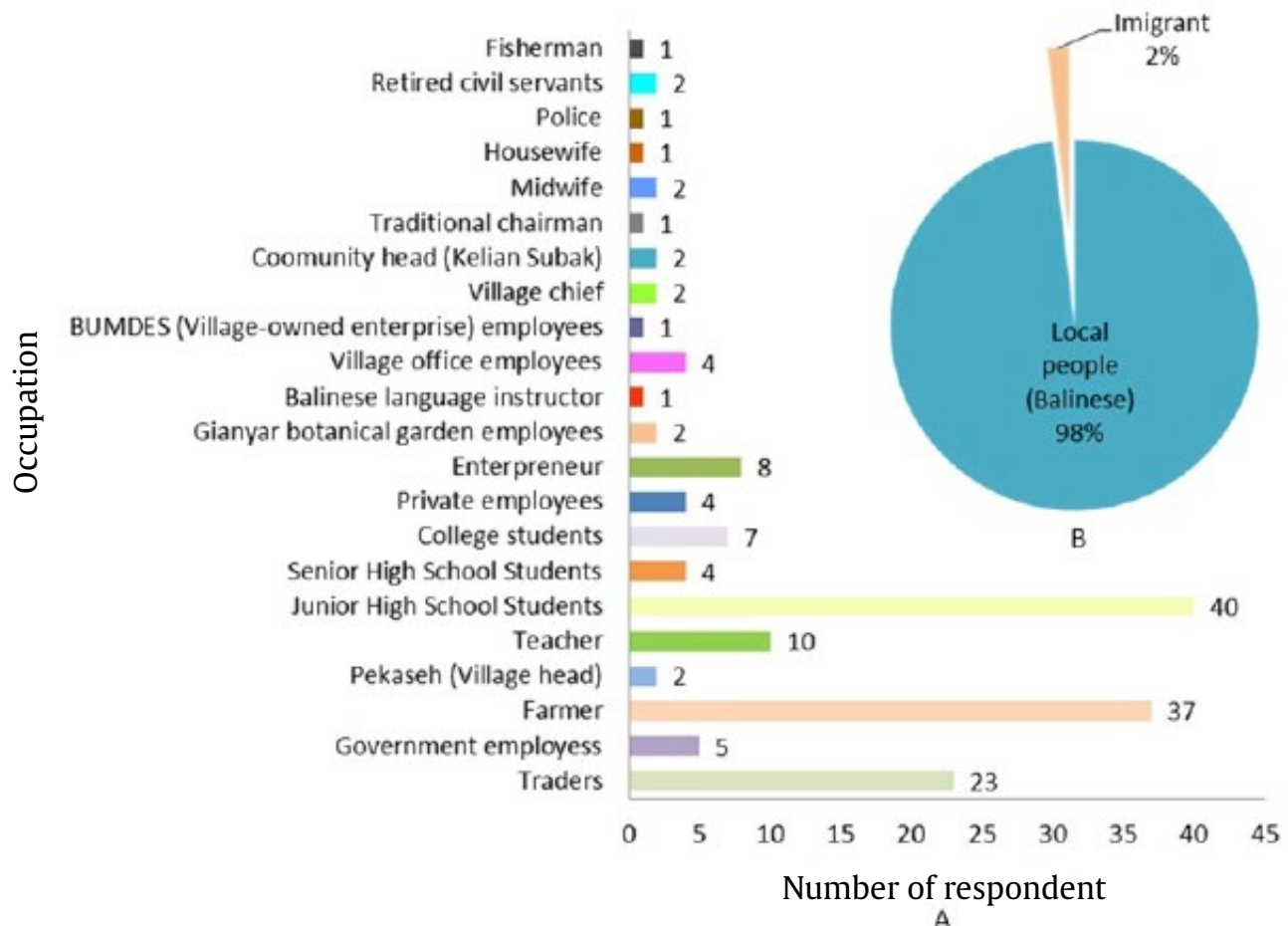

Figure 3. Ratio of respondents' occupations (A) and ethnicities (B) 


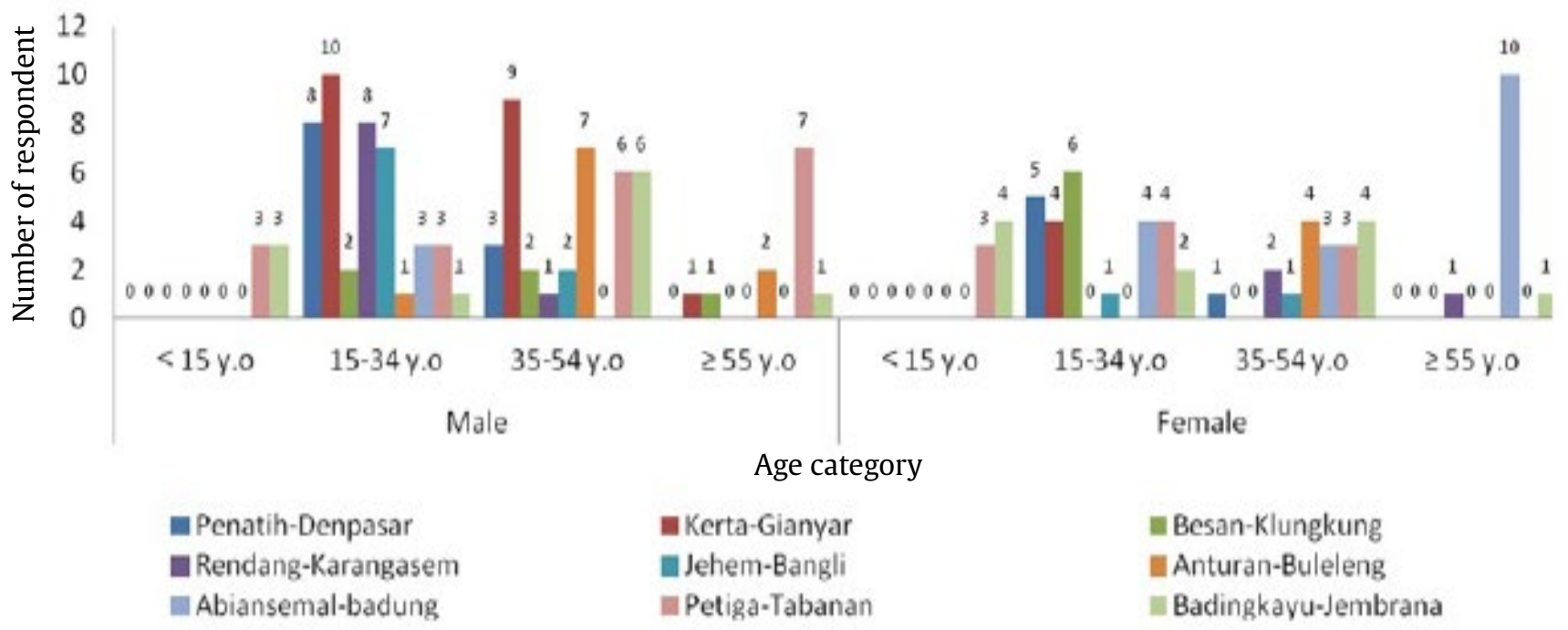

Figure 4. Ratio of respondents' gender and groups of age in the nine representing villages

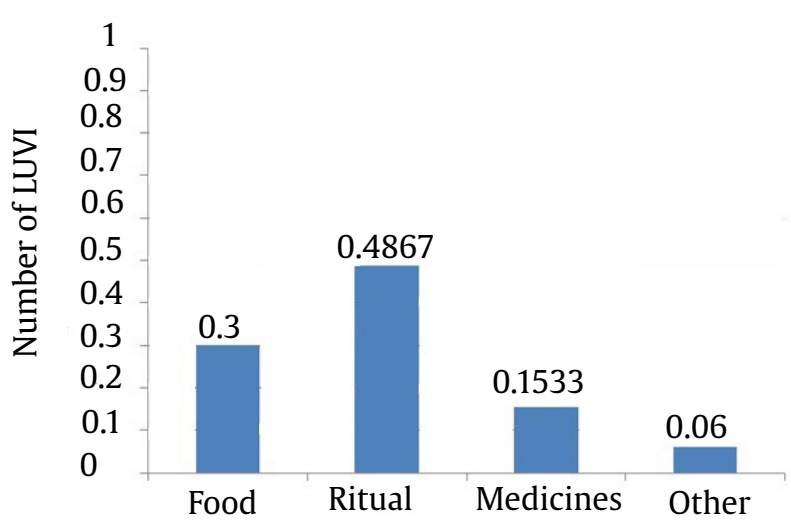

Figure 5. Analysis of local user value index (LUVI) toward bananas in four category of uses, by the people of Bali

was carried out during focused group discussion at each study site. The respondents were asked to mention the variants of bananas that present in their area. This free listing aimed to find out the local people's perception of the diversity of banana species as well as to document local names of banana variants. Most people were familiar with bananas that are often cultivated or consumed daily such as biu susu, biu saba, and biu mas. The results of free listing and observations from local bananas are presented in Table 2.

Our survey discovered 14 varieties of bananas that are often used by the community to support daily needs. The LUVI per category from 9 study sites are presented in Table 3.

\section{Discussion}

\subsection{Banana for Ritual}

The Balinese community is predominantly Hindu, with traditions and local wisdoms that are very well preserved. Banana is a key component that must present in every prayer or offering to the Gods (Surata et al. 2015). Plants used for ceremonial ritual needs are called as Upakara plants. The value of LUVI showed that pisang ambon hijau or biu lumut obtain the highest LUVI value (0.050), then biu mas and biu kayu with 0.036 and 0.028 of LUVI respectively. However, the interview showed different results, according to most people opinion biu kayu is the most important banana for ritual activities.

The discrepancy between LUVI scores and interview results were possibly due to the different values given by the respondents based on the intensity of using a certain banana. Lower value could be given for bananas that are only used in certain ceremonies and higher for the ones used in daily prayers. Another influencing factor could be the judgement of respondents were based on economic and scarcity reasons (Hapsari et al. 2015).

Based on observations during the expedition, there were various kinds of offering used by the Hindu Balinese Society. The most common one, which was found almost all the time in many places, is the offering of canang sari. Canang sari is used for daily offering, while for the big ceremonies banten is used. Canang sari is primarily made of banana or coconut leaves. Canang consists of several colored flowers that symbolize the wind direction, pandan leaves (Pandanus amarylifolius), and base or betel leaf (Piper betle) as the core (porosan). Banten is bigger than canang, it is formed by pile of leaf dishes stacked by plugging in a banana spade. Some fruits are arranged in a spherical form at the bottom of banten and banana at the back. Above the fruits, sit some cakes, and then chicken meat or pork at the top (Lugrayasa 2004). However, according to some respondents the components of banten could be customized adjusting to the financial condition of the ones making this offering.

Based on the emic perception (Rai et al. 2016), Balinese community put offerings in front of the house with a complementary arak (wine) or brem 


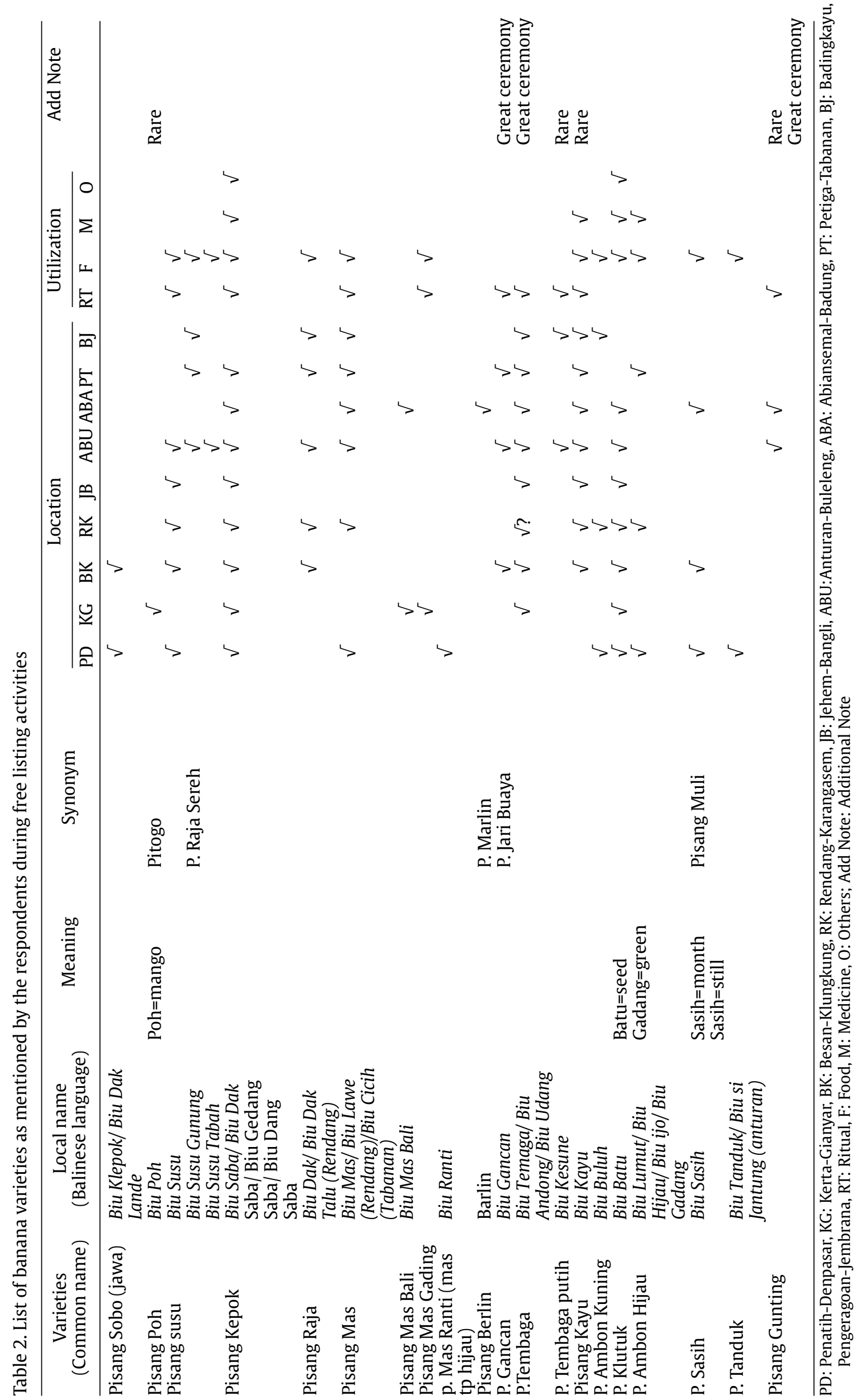




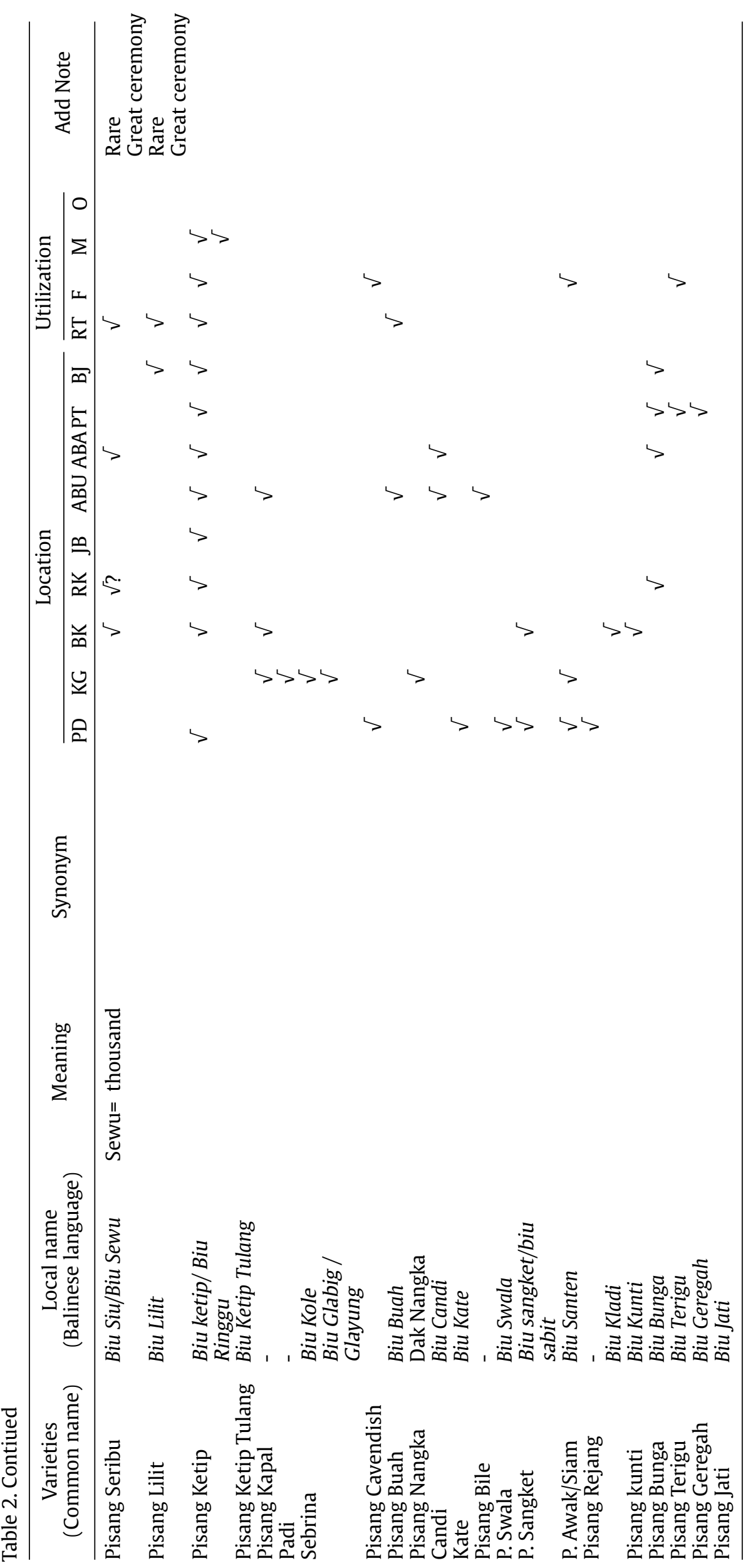


Table 3. Analysis of local user value index (LUVI) toward 14 discovered banana varieties in Bali, grouped in the four categories of uses

\begin{tabular}{|c|c|c|c|c|c|c|c|}
\hline \multicolumn{8}{|c|}{ Utilization Category } \\
\hline \multicolumn{2}{|c|}{ Food } & \multicolumn{2}{|c|}{ Ritual } & \multicolumn{2}{|c|}{ Medicine } & \multicolumn{2}{|c|}{ Others } \\
\hline Varieties & LUVI & Varieties & LUVI & Varieties & LUVI & Varieties & LUVI \\
\hline Biu Susu & 0.046 & Biu Susu & 0.028 & Biu Susu & 0.027 & Biu Susu & 0.025 \\
\hline Biu Saba & 0.020 & Biu Saba & 0.023 & Biu Saba & 0.033 & Biu Saba & 0.023 \\
\hline Biu Lumut & 0.032 & Biu Lumut & 0.050 & Biu Lumut & 0.040 & Biu Lumut & 0.019 \\
\hline Biu Mas & 0.015 & Biu Mas & 0.036 & Biu Mas & 0.019 & Biu Mas & 0.023 \\
\hline Biu Buluh & 0.031 & Biu Buluh & 0.021 & Biu Buluh & 0.017 & Biu Buluh & 0.019 \\
\hline Biu Dak Raja & 0.026 & Biu Dak Raja & 0.025 & Biu Dak Raja & 0.022 & Biu Dak Raja & 0.023 \\
\hline Biu Gancan & 0.003 & Biu Gancan & 0.009 & Biu Gancan & 0.008 & Biu Gancan & 0.023 \\
\hline Biu Temage & 0.011 & Biu Temage & 0.005 & Biu Temage & 0.002 & Biu Temage & 0.018 \\
\hline Biu Ketip & 0.017 & Biu Ketip & 0.014 & Biu Ketip & 0.030 & Biu Ketip & 0.023 \\
\hline Biu Sasih & 0.003 & Biu Sasih & 0.014 & Biu Sasih & 0.013 & Biu Sasih & 0.019 \\
\hline Biu Batu & 0.006 & Biu Batu & 0.004 & Biu Batu & 0.012 & Biu Batu & 0.041 \\
\hline Biu Кауu & 0.016 & Вiu Кауи & 0.028 & Biu Kayu & 0.034 & Вiu Кауи & 0.017 \\
\hline Biu Tanduk & 0.015 & & & Biu Raja Sereh & 0.008 & Biu Raja Sereh & 0.004 \\
\hline Biu Raja Sereh & 0.007 & & & & & & \\
\hline
\end{tabular}

Top Tree

\begin{tabular}{|c|c|c|c|c|c|c|c|}
\hline Varieties & LUVI & Varieties & LUVI & Varieties & LUVI & Varieties & LUVI \\
\hline \multicolumn{8}{|c|}{ Utilization Category } \\
\hline \multicolumn{2}{|c|}{ Food } & \multicolumn{2}{|c|}{ Ritual } & \multicolumn{2}{|c|}{ Medicine } & \multicolumn{2}{|c|}{ Other } \\
\hline Biu Susu & 0.046 & Biu Lumut & 0.050 & Biu Lumut & 0.040 & Biu Batu & 0.041 \\
\hline Biu Lumut & 0.032 & Biu Mas & 0.036 & Вiи Кауи & 0.034 & Biu Susu & 0.025 \\
\hline Biu Buluh & 0.031 & Вiи Кауи & 0.028 & Biu Saba & 0.033 & Biu Saba & 0.023 \\
\hline
\end{tabular}

stored in containers made from banana leaves. They believe that this is able to resist evil or illness. It may indicate local knowledge of the Balinese community, from ethic perception, alcohol in arak and brem can serve as disinfectant and antiseptic.

Based on FGD results in Kerta Village -Gianyar, the use of bananas as part of offerings has its own philosophy in symbolizing the color of the wind direction. Biu gancan represents white color as east symbol, biu kayu represents black color as the symbol of north direction, biu mas represents yellow color of west symbol, biu temage represents red color symbol of south direction, and biu buah represents green color symbol northwest. The wind direction symbolizes the manifestations of the Gods. Hence, the utilization of banana and other plants in rituals are not only based on religious values, but also on aesthetic value. Psychologically, the beauty of colors and the arrangement of offerings can create a feeling of peace (Rai et al. 2016).

\subsection{Banana for Food}

For Balinese people, bananas is also a source of food in addition to its main function as the component of offerings in ritual and tradition. The highest LUVI in food category was obtained by biu susu (0.046), biu lumut (0.032), and biu buluh (0.031). Some varieties can be consumed as fresh fruit or cooked into various dishes (Jumari 2000; Rai et al. 2016). One of the most common dishes from banana stem is jukut ares or Balinese banana pork. Jukut ares is made from young banana stems mixed with pork, or other meat such as chicken, duck and cow with a mixture of Balinese spices. The spices consist of onion (Allium cepa var. aggregatum), garlic (Allium sativum), red pepper (Capsicum anuum), cayenne (Capsicum frutescens), bay leaves (Syzygium polyantum), galangal (Alpinia galanga), turmeric (Curcuma longa), ginger (Zingiber officinale), kencur (Kaempferia galanga), tamarind (Tamarindus indica), salt and shrimp paste.

\subsection{Banana for Medicine}

Utilization of plants for traditional medicine by Balinese people is an intellectual property right that needs to be preserved. The knowledge of traditional Balinese medicine (Usada) introduced by ancestors is a valuable knowledge of healing that is imbued with Hindu values derived from lontar (Prastika 2009). Bananas have long been used as a remedy for some diseases. Based on the recapitulation value of LUVI in 9 study sites, the three most important banana cultivars for medicine category are biu lumut (0.040), biu kayu (0.034), and biu saba (0.033). 
Based on the questionnaire, some respondents claimed to have used banana as a traditional medicine and others claimed never. Users of traditional medicine from banana were most found in Badingkayu village of Jembrana regency, while most respondents who never use bananas as traditional medicine were found in the Kerta village of Gianyar regency (Pongsipulung et al. 2012).

\subsection{Other Uses of Banana}

In addition to the uses of bananas as food, medicine and in rituals, bananas are also used for other purposes such as for livestock feed, ornament or decoration and food wrapping. The highest LUVI in the uses category of others was obtained by biu batu (0.041), biu susu (0.025), and biu saba (0.023).

\subsection{Indigenous Knowledge Transmission}

The knowledge and skill of using banana plants for the daily needs of people in Bali is recognized by most of the respondents (98\%) to have come from their parents. This includes the knowledge of using bananas in ritual needs, food, and medicine. While $2 \%$ of respondents claimed to have obtained the knowledge for using bananas as drugs from a healer. These results showed that the knowledge transmission of banana in Balinese society is predominantly vertical, from parents to their children. The process of acquiring local knowledge is obtained by listening or observing, and direct practice. In fact, by a way of habituation from an early age, then the younger generation can understand how to use bananas for daily life (Trombulak et al. 2004).

At this time, local knowledge degradation occurs, as the elders expressed that the strategies undertaken for local bananas still exist when it is needed during ceremony by planting bananas on good days or during the full moon, which is done every 15 days. While adult and young respondents do not to do so.

\subsection{Advantages and Problems of Local Banana}

Bananas for the Balinese are also an important commodity with high economic value (Figure 6).

Table 4. The uses of bananas in others category

\begin{tabular}{|c|c|c|}
\hline Local name & Utilization & Part used \\
\hline \multirow{3}{*}{ Biu Saba } & Craft & $\begin{array}{l}\text { Pseudo stem } \\
\text { sheaths }\end{array}$ \\
\hline & Fertilizer & Tuber \\
\hline & Rope & $\begin{array}{l}\text { Pseudo stem } \\
\text { sheaths }\end{array}$ \\
\hline \multirow[t]{2}{*}{ Biu Batu } & Wrapper & Leaf \\
\hline & Animal feed & $\begin{array}{l}\text { old banana } \\
\text { stems }\end{array}$ \\
\hline \multirow[t]{2}{*}{ Any banana } & $\begin{array}{l}\text { wedding } \\
\text { decoration display }\end{array}$ & shoots \\
\hline & $\begin{array}{l}\text { traditional toys: } \\
\text { sword, gun }\end{array}$ & Leaf bones \\
\hline
\end{tabular}

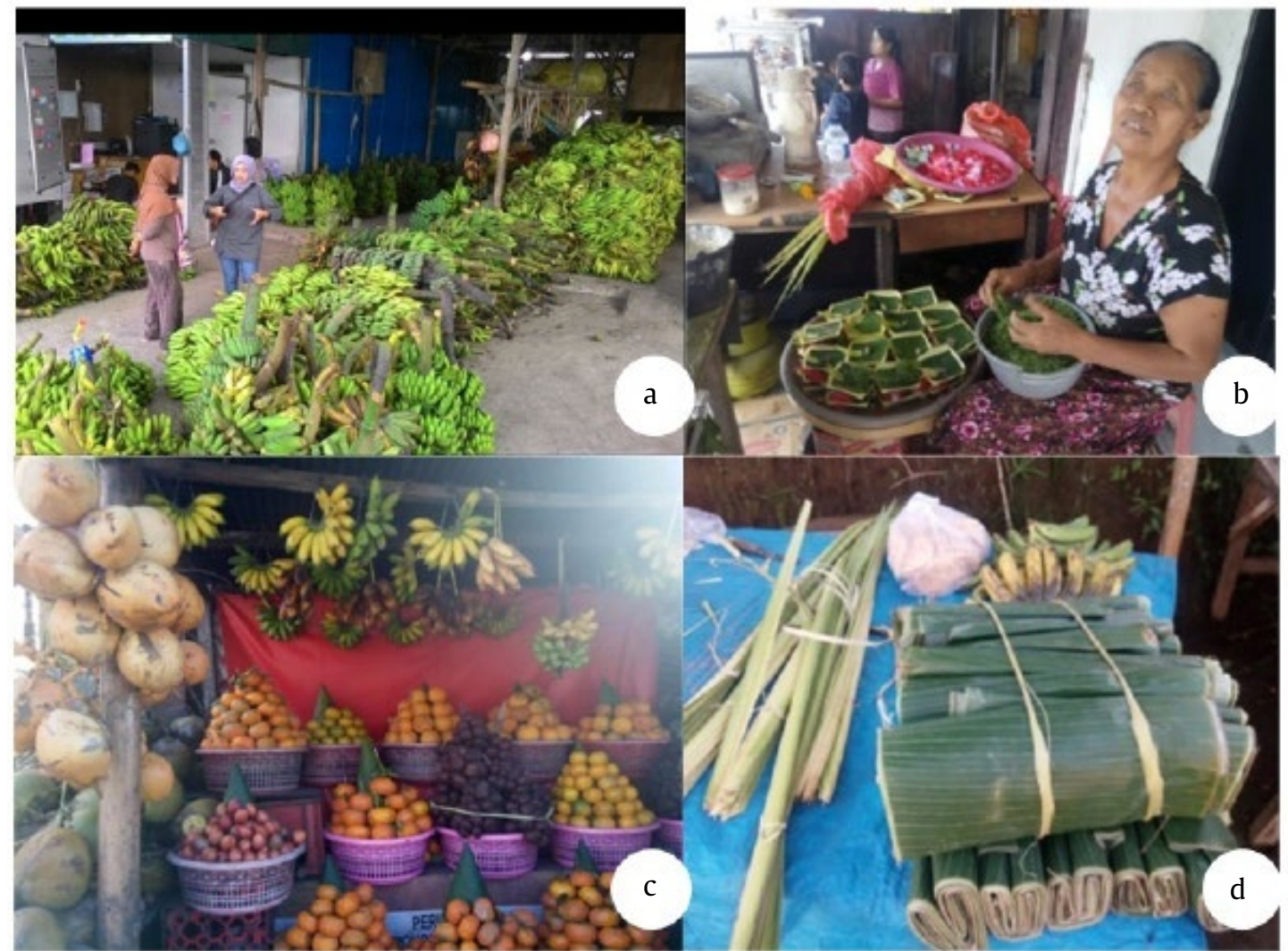

Figure 6. Banana for various commodities. (a) the middleman; (b) banana leaf for canangsari, (c) fruits at Kintamani; and $(\mathrm{d})$ banana leaf selling in traditional market 
Bananas with the highest price are biu susu and biu kayu. Biu susu is seek for its unique flavor, while biu kayu holds a special role in ritual needs but are rare to get. The price of banana fruit ranges from Rp. 1,500 - Rp. 2,000/finger or Rp. 25,000 - 30,000/hand. Banana leaves can be sold in the market as leaf pack rolls, or in the form of canang. Canang is sold for Rp. 5,000/plastic bag containing 6 pieces or Rp. 10,000 / plastic bag with 12 pieces. These prices soar rapidly commencing major Hindu feasts, such as Galungan and Kuningan.

One of the main problems related to Balinese bananas according to the respondents is the high level of demand, especially for religious and cultural rituals. This condition is worsen by the limited existence of some cultivars, which are already categorized as rare such as biu kayu. Bananas are also susceptible to diseases, especially fusarium wilt or people know it as mati bujang (die young). Hence, to anticipate the shortage of bananas, some markets are getting daily supply from outside Bali such as Java island. In addition, local banana prices are more expensive than supplied bananas from Java or Lombok. However, although the supply of bananas has been supplied from outside Bali, there is still a fanaticism of some people who only uses local bananas on the grounds of the value of holiness (Lugrayasa 2004).

The results of this ethnobotany study are expected to be a consideration for increasing the uses of bananas as food, in rituals, medicine, handicraft, or even in the economy. In addition, the most important thing is how to manage the natural resources of the environment to improve the local germplasm conservation program of Balinese banana (Simmonds 1959).

There are approximately 44 banana varieties in Bali, with some are invasive species such as biu bile. Utilization of banana plants in the province of Bali in daily life includes three main categories as ritual components, consumpti on and medicine. People usually uses banana mainly for rituals component, followed by for food and medicine. The highest LUVI in food category was received by biu susu (0.046), which is sweet with soft texture. Biu susu is also sold in relatively higher price. The highest LUVI of the ritual category is obtained by biu lumut (0.050) and biu ambon hijau (0.040) in the medicine category. Biu batu received LUVI with value 0.041 as food wrappings.

\section{Acknowledgements}

This study was fully supported by Bali International Research Center for Banana, which is gratefully acknowledged.

\section{References}

Bernard HR. 2002. Research Methods in Anthropology: Qualitative and Quantitative Approaches, third ed. Walnut Creek, CA.

Daniells J et al. 2001. Musalogue: A Catalogue of Musa Germplasm: Diversity in the genus Musa. International Network for the Improvement of Banana and Plantain/INIBAP, Montpellier.

De Beer J, Van Wyk BE. 2011. Doing an ethnobotanical survey in the life science classroom. The Am. Biol. Teach 2(73):90-97.

Dickinson A 2013. A study of the variation in traditional knowledge in and around Nagarkoodal Village, Tamil Nadu, India [Undergraduate Thesis]. Scarborough, Canada: University of Toronto.

Espino RRC et al. 1992. Musa L. (edible cultivars), in: Verheij, E.W.M., Coronel, R.E. (Eds.). Plant Resources of South-East Asia No.2: Edible fruits and nuts. PROSEA Foundation Bogor.

Hapsari L et al. 2015. Diversity of bananas (Musa spp.) in Madura Island East Java: exploration and inventory. J Biol Env Sci 6(3):256-264.

Hapsari L et al. 2017. Ethnobotanical survey of Bananas (Musaceae) in six district of East Java Indonesia. Biodiversitas 18(1):160-174.

Henderson F et al. 2012. Ethnobotanical research skills for student of underrepresented minorities in STEM disciplines. Ethno. Res. Apply 10:389-402.

Jumari PA 2000. Phenetic relationship of banana cultivars in Java. Biologi 2(9):531-542.

Lugrayasa IN. 2004. Pelestarian pisang dan manfaat dalam upacara adat hindu Bali. In: Prosiding Seminar Konservasi Tumbuhan Upacara Agama Hindu.

Martin GJ 2004. Ethnobotany: A methods manual. in: Walters M (ed.). 'People and Plants' Conservation Manuals. WWF International UNESCO, Royal Botanic Gardens Kew. Chapman \& Hall, London.

Oishi, SM 2002. How to Conduct in-Person Interviews for Surveys. SAGE Publications, London, United Kingdom.

Pongsipulung GR et al. 2012. Formulasi dan pengujian salep ekstrak bonggol pisang terbuka pada kulit tikus putih jantan galur Wistar (Rattus norvergicus). Pharmacon 1(2):7-13.

Prastika, IN 2009. Usada: Pengobatan Tradisional Bali. Universitas Hindu Indonesia, Bali.

Rai N et al. 2016. Buah-buahan Lokal Bali: Jenis, Pemanfaatan, dan Potensi pengembangannya. Palawa Sari, Bali.

Simmonds NW. 1959. Bananas. Longman, New York.

Surata IK et al. 2015. Studi etnobotani tanaman upacara hindu Bali sebagai upaya pelestarian kearifan lokal. Jurnal Kajian Bali 5(2):265-284.

Suryadarma IGP 2008. Diktat Kuliah Etnobotani. Jurusan Pendidikan FPMIPA UNY, Yogyakarta.

Trombulak SC et al. 2004. Principles of conservation biology recommended guidelines for conservation literacy from the education committee of the society for conservation biology. Conservation Biol 18(5):11801190.

Tongco MDC 2007. Purposive sampling as a tool for informant selection. J Plant People Appl Res 5:147-158. 